\title{
PENGARUH TAX AMNESTY TERHADAP KEPATUHAN WAJIB PAJAK DENGAN PENGETAHUAN PEPAJAKAN SEBAGAI PEMODERASI
}

\author{
Axel \\ Mulyani* \\ Program Studi Akuntansi, Institut Bisnis dan Informatika Kwik Kian Gie \\ Jl. Yos Sudarso Kav.87, Jakarta 14350
}

\begin{abstract}
Tax is the largest source of state revenue for the Indoensian budget. Efforts by the government to obtain state revenues through taxes are still not effective. Therefore, the government held a socialization on taxes and set tax amnesty policy. This study aims to determine the effect of tax amnesty on individual entrepreneurs taxpayer compliance with knowledge of taxation as a moderating variable. The population of this study is an individual entreprenuers taxpayer who conducts business activities in ITC Cempaka Mas. Data and information obtained from the questionnaires filled out by respondents, 100 individual entrepreneurs taxpayers. This research was conducted by distributing questionnaires with judgmental sampling technique. This research use likert scale; SPSS 22; Test Validity and Reliability; Classic assumption test; Hypothesis testing. The result of data analysis shows that tax amnesty have positive and significant effect to individual entrepreneurs taxpayer compliance. Taxation knowledge has a positive and significant effect on taxpayer compliance of private entrepreneur. Another result that can be concluded is the knowledge of taxation has no effect in moderating the relationship between tax amnesty and individual entrepreneurs taxpayer compliance
\end{abstract}

Keywords : Tax Amnesty, Taxation Knowledge, and Individual Entrepreneurs Taxpayer Compliance

\begin{abstract}
ABSTRAK
Pajak merupakan sumber penerimaan negara terbesar dalam struktur anggaran pendapatan dan belanja negara (APBN). Upaya pemerintah guna meningkatkan penerimaan negara melalui pajak masih dianggap belum optimal. Oleh sebab itu pemerintah mengadakan sosialisasi tentang pajak dan menetapkan kebijakan tax amnesty. Penelitian ini bertujuan untuk mengetahui pengaruh tax amnesty terhadap kepatuhan wajib pajak orang pribadi usahawan dengan pengetahuan perpajakan sebagai variabel moderasi. Populasi Penelitian ini adalah wajib pajak orang pribadi yang melakukan kegiatan usaha di ITC Cempaka Mas. Data dan informasi yang diperoleh dari hasil kuesioner yang diisi oleh responden, yaitu 100 wajib pajak orang pribadi usahawan. Penelitian ini dilakukan dengan cara penyebaran kuesioner dengan teknik judgemental sampling. Penelitian ini menggunakan skala likert; SPSS 22; Uji Validitas dan Reliabilitas; Uji Asumsi Klasik; Uji Hipotesis. Hasil analisis data menunjukan bahwa tax amnesty berpengaruh positif dan signifikan terhadap kepatuhan wajib pajak orang pribadi usahawan. Pengetahuan perpajakan berpengaruh positif dan signifikan terhadap kepatuhan wajib pajak orang pribadi usahawan. Hasil lain yang dapat disimpulkan adalah pengetahuan perpajakan belum cukup bukti memiliki pengaruh dalamn memoderasi hubungan antara tax amnesty dan kepatuhan wajib pajak orang pribadi usahawan.
\end{abstract}

Kata Kunci : Tax Amnesty, Pengetahuan Perpajakan, dan Kepatuhan Wajib Pajak Orang Pribadi Usahwan

*Alamat kini:Institut Bisnis dan Informatika Kwik Kian Gie,Jl. Yos Sudarso Kav 87,Sunter,Jakarta 14350

Penulis untuk Korespondensi: (021) 65307062 Ext. 708. Email: mulyani@kwikkiangie.ac.id 


\section{Pendahuluan}

Pajak merupakan sumber penerimaan negara terbesar untuk struktur anggaran pendapatan dan belanja negara (APBN). Pajak merupakan kontribusi wajib kepada negara oleh orang pribadi atau badan yang sifatnya memaksa berdasarkan undang-undang.

Menyadari akan besarnya peranan pajak untuk menggerakkan roda pemerintah dan pembangunan, sejak tahun 1983 telah dilakukan usaha-usaha dalam bentuk reformasi sistem perpajakan nasional. Salah satu upaya pemerintah yaitu dengan merubah sistem pemungutan pajak dari office assesment system menjadi self assessment system.

Self assessment system adalah sistem pemungutan pajak yang memberi wewenang kepada Wajib Pajak untuk menentukan sendiri besarnya pajak yang terutang. Perubahan sistem perpajakan tersebut dimaksudkan untuk menjadikan wajib pajak sebagai subjek yang lebih mandiri dalam memenuhi kewajiban perpajakannya.

Dalam mencapai target pajak yang ditetapkan dalam APBN, terdapat masalah yang dapat menghambat proses pengumpulan pajak, salah satunya adalah kepatuhan wajib pajak. Kepatuhan wajib pajak adalah wajib pajak yang disiplin dan taat, serta tidak memiliki tunggakan atau keterlambatan penyetoran pajak.

Kepatuhan perpajakan dibagi ke dalam dua yaitu kepatuhan formal dan kepatuhan material. Kepatuhan formal adalah suatu keadaan dimana wajib pajak memenuhi kewajiban secara formal sesuai dengan ketentuan dalam undang - undang perpajakan. Kepatuhan material adalah suatu keadaan dimana wajib pajak secara hakikatnya memenuhi semua ketentuan material perpajakan yaitu sesuai isi dan jiwa undangundang perpajakan.

Peningkatan kepatuhan wajib pajak dapat dipengaruhi oleh pengetahuan perpajakan setiap wajib pajak. Pengetahuan perpajakan adalah pengetahuan mengenai ketentuan umum dan tata cara perpajakan, pengetahuan mengenai hak dan kewajiban wajib pajak serta prosedur pembayaran, pemungutan dan pelaporan pajak. Melihat dari potensi masalah pengetahuan bahwa tingkat pengetahuan perpajakan mempengaruhi tingkat efektivitas perolehan pajak Negara.

Berdasarkan fenomena yang terjadi, terdapat wajib pajak yang cenderung memiliki pengetahuan perpajakan sehingga mereka sengaja menghindari kewajiban perpajakannya (Tax Avoidance \& Tax Evasion). Dilansir dari artikel yang berisi Panama Papers, dijelaskan bahwa secara internasional telah terbukti keinginan masyarakat untuk menghindari pajak tinggi akan selalu terjadi (beritasatu.com, 2017).

Tingkat kepatuhan wajib pajak belum sesuai dengan keinginan pemerintah. Upaya yang dilakukan pemerintah untuk memperoleh penerimaan Negara melalui pajak masih belum efektif karena masih ada wajib pajak yang tidak memiliki pengetahuan perpajakan yang cukup dan membuat mereka tidak sengaja menghindari kewajiban perpajakannya. Pemerintah dalam hal ini melakukan sosialisasi untuk meningkatkan efektivitas program. Dilansir dari artikel yang berisi pemerintah melalui Direktorat Jenderal Pajak (DJP) mengadakan sosialisasi pajak kepada siswa dan mahasiswa guna untuk memperkenalkan generasi muda terhadap pentingnya membayar pajak untuk pembangunan infrastruktur. DJP menjelaskan bahwa memperkenalkan pajak pada generasi muda sejak dini penting agar alam bawah sadar mereka tertanam semangat untuk wajib membayar pajak (berisatu.com, 2017).

Pemerintah melalui Direktorat Jenderal Pajak (DJP) sampai saat ini masih berusaha meningkatkan kepatuhan wajib pajak dan mengejar target penerimaan pajak. Salah satu usaha terbaru adalah dengan menetapkan kebijakan pengampunan pajak yang dikenal dengan tax amnesty. 
Pelaksanaan Tax Amnesty merupakan upaya pemerintah dalam meningkatkan kepatuhan. Tax amnesty diharapkan mampu meningkatkan subjek pajak dan objek pajak. Subjek pajak berupa penambahan wajib pajak, sedangkan objek pajak berupa kembalinya dana-dana dari luar negeri.

Fasilitas yang didapatkan bagi wajib pajak yang mengikuti program Tax amnesty adalah mendapatkan pengampunan atas pajak yang seharusnya terutang, serta penghapusan sanksi administrasi dan sanksi pidana.

Berdasarkan fenomena yang terjadi bahwa dalam pelaksanaan Tax amnesty, implementasi perpajakan di Indonesia masih mempunyai beberapa permasalahan. Salah satu permasalahannya adalah kepatuhan wajib pajak yang masih rendah. Menurut Yustinus Prastowo, Pendiri Center for Indonesia Tax Analysis (CITA) adanya kebijakan tax amnesty dapat memulihkan wajib pajak untuk patuh dan menambah daftar wajib pajak baru yang selaras dengan kondisi global (hukumonline.com, 2016).

Namun, menurut Mohammad Faisal selaku Direktur Eksekutif Center of Reform on Economics (CORE) Indonesia mengatakan tingkat partisipasi wajib pajak (WP) yang memanfaatkan tax amnesty masih rendah (cnnindonesia.com, 2017).

Sosialisasi program kebijakan tax amnesty telah dilakukan oleh Direktorat Jenderal Pajak dan pemerintah untuk memberikan pengetahuan dan pemahaman tentang kebijakan program tersebut. Pengetahuan perpajakan digunakan sebagai variabel moderasi. Variabel moderasi adalah variabel independen yang akan memperkuat atau memperlemah hubungan antara variabel independent lainnya terhadap variabel dependen. Variabel moderasi digunakan dengan maksud, apabila pengetahuan dan pemahaman wajib pajak terhadap peraturan perpajakan baik, maka wajib pajak dapat patuh terhadap peraturan perpajakan yang ada, dimana dalam hal ini adalah menjadi peserta tax amnesty.

Dari uraian diatas, maka peneliti ingin mengangkat topik yang terkait dengan tax amnesty, pengetahuan perpajakan dan kepatuhan wajib pajak dengan tema "Pengaruh Tax Amnesty Terhadap Kepatuhan Wajib Pajak Dengan Pengetahuan Perpajakan Sebagai Variabel Moderasi”.

\section{Landasan Teori dan Hipotesis}

Pajak

Pajak merupakan sejumlah uang yang wajib dibayarkan oleh seorang warga negara kepada pemerintahnya. Pajak bersifat memaksa dan tidak mendapatkan imbalan secara langsung. Waluyo (2017:6), pajak memiliki dua fungsi yaitu fungsi budgeter dan fungsi mengatur. Sebagai fungsi budgeter, pajak berfungsi sebagai sumber dana yang diperuntukkan untuk membiayai pengeluaranpengeluaran negara. Sebagai contoh: dimasukannya pajak dalam APBN sebagai penerimaan dalam negeri. Sebagai fungsi mengatur, Pajak berfungsi sebagai alat untuk mengatur atau melaksanakan kebijakan dibidang sosial dan ekonomi. Sebagai contoh yaitu dikenakannya pajak yang lebih tinggi terhadap minuman keras, demikian pula terhadap barang mewah.

\section{Kepatuhan Wajib Pajak}

Menurut Safri dalam Rahayu (2013:138), pengertian kepatuhan perpajakan adalah sebagai suatu keadaan dimana wajib pajak memenuhi semua kewajiban perpajakan dan melaksanakan hak perpajakannya. Kepatuhan perpajakan dibagi ke dalam dua, yaitu kepatuhan formal dan kepatuhan material.

Kepatuhan formal merupakan suatu keadaan dimana wajib pajak memenuhi kewajiban secara formal sesuai dengan 
ketentuan dalam undang-undang perpajakan. Sedangkan kepatuhan material merupakan suatu keadaan dimana wajib pajak secara hakikatnya memenuhi semua ketentuan material perpajakan yaitu sesuai isi dan jiwa undang-undang perpajakan. Selanjutnya, Peraturan Menteri Keuangan Republik Indonesia Nomor 74/PMK.03/2012 pasal (2) menjelaskan bahwa seseorang dapat ditetapkan sebagai wajib pajak dengan kriteria tertentuadapun kriteria tersebut meliputi: a) Tepat waktu dalam menyampaikan Surat Pemberitahuan (SPT). B) Tidak mempunyai tunggakan pajak untuk semua jenis pajak, kecuali tunggakan pajak yang telah memperoleh izin mengangsur atau menunda pembayaran pajak. c) Laporan keuangan diaudit oleh akuntan publik atau lembaga pengawasan keuangan pemerintah dengan pendapat wajar tanpa pengecualian selama tiga tahun berturut-turut. d) Tidak pernah dipidana karena melakukan tindak pidana di bidang perpajakan berdasarkan putusan pengadilan yang telah mempunyai kekuatan hokum tetap dalam jangka waktu lima tahun terakhir.

\section{Tax Amnesty}

Tax amnesty adalah penghapusan pajak yang seharusnya terhutang, tidak dikenai sanksi administrasi perpajakan dan sanksi pidana di bidang perpajakan, dengan cara mengungkapkan harta dan membayar uang tebusan (UU Republik Indonesia Nomor 11 Tahun 2016). Mendapatkan penghapusan pajak artinya data laporan yang ada selama ini dianggap telah diputihkan dan atas beberapa utang pajak juga dihapuskan (lembagapajak.com).

Pemerintah Indonesia mulai memperlakukan Tax Amnesty pada pertengahan tahun 2016. Adapun tujuan dari dilaksanakannya program Tax Amnesty di Indonesia adalah sebagai berikut;

1) Mempercepat pertumbuhan dan restrukturisasi ekonomi melalui pengalihan harta, yang akan berdampak terhadap peningkatan likuiditas domestik, perbaikan nilai tukar rupiah, penurunan suku bunga, dan peningkatan investasi.

2) Mendorong reformasi perpajakan menuju sistem perpajakan yang lebih berkeadilan serta perluasan basis data perpajakan yang lebih valid, komprehensif, dan terintegrasi.

3) Meningkatkan penerimaan pajak yang digunakan untuk pembiayaan pembangunan.

Menurut Direktorat Jenderal Pajak, manfaat dari diberlakukannya tax amnesty, meliputi;

1) Peningkatan Tax Ratio melalui pencapaian target penerimaan pajak.

2) Perluasan basis data perpajakan yang lebih valid, komprehensif dan terintegrasi. Dalam arti dapat memperoleh data yang lebih lengkap tentang Wajib Pajak.

3) Peningkatan investasi dan likuiditas okum ta, perbaikan nilai tukar rupiah, dan penurunan suku bunga.

4) Dalam jangka pendek dapat meningkatkan penerimaan negara. Manfaat tersebut diperoleh dari uang tebusan yang dibayar Wajib Pajak sebagai pengganti pajak yang belum/tidak dibayar serta penghapusan sanksi.

\section{Pengetahuan Perpajakan}

Pengetahuan merupakan sesuatu yang diketahui. Notoatmodjo (2013:138), menyatakan bahwa pengetahuan hasil dari tahu seseorang terhadap objek tertentu melalui indera yang dimilikinya melalui mata, telinga, hidung dan sebagainya. Pengetahuan dikaitkan dengan segala sesuatu yang diketahui berkaitan dengan proses belajar. Contohnya seperti pengetahuan yang ada dalam mata pelajaran suatu kurikulum di sekolah. Terdapat enam tingkat pengetahuan, yaitu:

1) Tahu (Know). Tahu diartikan sebagai mengingat sesuatu materi yang telah dipelajari sebelumnya. Mengingat kembali 
(recall) sesuatu yang spesifik dan seluruh bahan yang dipelajari atau rangsangan yang telah diterima.

2) Memahami (Comprehension). Memahami diartikan sebagai suatu kemampuan untuk menjelaskan secara benar tentang objek yang diketahui.

3) Aplikasi (Application). Aplikasi diartikan sebagai kemampuan untuk menggunakan meteri yang telah dipelajari pada situasi atau kondisi real (sebenarnya).

4) Analisis (Analysis). Analisis adalah suatu kemampuan untuk menjabarkan meteri atau suatu objek ke dalam komponenkomponen, tetapi masih di dalam satu struktur organisasi dan masih ada kaitannya satu sama lain.

5) Sintesis (Synthesis). Sintesis menunjuk kepada suatu kemampuan untuk meletakkan atau menghubungkan bagianbagian di dalam suatu bentuk keseluruhan yang baru.

6) Evaluasi (Evaluation). Evaluasi ini berkaitan dengan kemampuan untuk melakukan penelitian atau penilaian terhadap suatu materi atau objek.

Pengetahuan terhadap ketentuan pajak bagi wajib pajak orang pribadi berarti mengetahui fungsi dan manfaat perpajakan. Selain itu, wajib pajak juga harus memahami bagaimana cara mengisi SPT, menghitung, membayar, dan melaporkan pajak yang terutang dengan benar dan tepat waktu. Rahayu (2013:140), menyatakan bahwa konsep pengetahuan atau pemahaman pajak meliputi: a) Pengetahuan mengenai ketentuan umum dan tata cara perpajakan. b) Pengetahuan mengenai sistem perpajakan di Indonesia. c) Pengetahuan mengenai fungsi perpajakan.

\section{Pengaruh Tax Amnesty terhadap Kepatuhan Wajib Pajak Orang Pribadi}

Tax amnesty merupakan suatu kebijakan yang dilakukan kembali oleh pemerintah guna untuk meningkatkan penerimaan Negara pada sektor perpajakan. Seorang wajib pajak harus memiliki pengetahuan dan pemahaman mengenai tax amnesty. Peneliti beranggapan bahwa kedua hal tersebut merupakan hal dasar bagi wajib pajak untuk mengikuti tax amnesty agar dapat meningkatkan kepatuhan wajib pajak.

Rahayu (2017), menyatakan bahwa Pengetahuan Perpajakan, Ketegasan Sanksi, dan Tax Amnesty memiliki pengaruh signifikan terhadap tingkat Kepatuhan Wajib Pajak. Sedangkan menurut Sari (2017), bahwa Pelayanan Fiskus berpengaruh negatif terhadap Kepatuhan Wajib Pajak., sedangkan Tax Amensty dan Pengetahuan Perpajakan berpengaruh positif terhadap Kepatuhan Wajib Pajak. Berdasarkan kedua penelitian tersebut maka dapat dirumuskan hipotesis penelitian sebagai berikut.

$\mathrm{H}_{1}$ : Tax Amnesty berpengaruh terhadap Kepatuhan Wajib Pajak Orang Pribadi Usahawan.

\section{Pengaruh Pengetahuan Perpajakan terhadap Kepatuhan Wajib Pajak Orang Pribadi}

Pengetahuan Pajak adalah wajib pajak orang pribadi yang tahu fungsi dan manfaat perpajakan. Jika wajib pajak mengerti manfaat perpajakan seperti cara menghitung, membayar dan melaporkan pajak, mara mereka akan senantiasa patuh dalam melaksanakan kewajiban perpajakannya. Peneliti beranggapan bahwa dengan tingkat pengetahuan yang baik, maka wajib pajak dapat menampilkan sikap yang positif dalam melaksanakan kewajiban perpajakannya sehingga berdampak baik pada kepatuhan wajib pajak.

Menurut Sari (2017), bahwa Pelayanan Fiskus berpengaruh negatif terhadap Kepatuhan Wajib Pajak., sedangkan Tax Amensty dan Pengetahuan Perpajakan berpengaruh positif terhadap Kepatuhan Wajib 
Pajak. Sedangkan menurut Rahayu (2017), bahwa Pengetahuan Perpajakan, Ketegasan Sanksi, dan Tax Amnesty memiliki pengaruh signifikan terhadap tingkat Kepatuhan Wajib Pajak. Berdasarkan penelitian tersebut maka dapat dirumuskan hipotesis penelitian sebagai berikut.

$\mathrm{H}_{2}$ : Pengetahuan Perpajakan berpengaruh terhadap Kepatuhan Wajib Pajak.

Pengaruh Pengetahuan Perpajakan sebagai Variabel Moderating dalam Hubungan antara Tax Amnesty dan Kepatuhan Wajib Pajak Orang Pribadi

Pengetahuan dan pemahaman mengenai peraturan perpajakan harus dimiliki oleh wajib pajak sebab kedua hal tersebut merupakan hal dasar bagi wajib pajak dalam menjalankan kewajiban perpajakannya. Dalam hal ini adalah melaksanakan kewajiban tax amnesty. Pengetahuan bisa dilakukan melalui sosialisasi. Sosialisasi program kebijakan tax amnesty telah dilakukan oleh Direktorat Jenderal Pajak dan pemerintah untuk memberikan pengetahuan dan pemahaman tentang kebijakan program tax amnesty. Peneliti beranggapan bahwa dengan pengetahuan perpajakan yang baik, maka wajib pajak dapat melaksanakan kebijakan tax amnesty dengan baik agar dapat meningkatkan kepatuhan wajib pajak.

Menurut Yani dan Noviari (2017), menyatakan bahwa Pengetahuan dan Pemahaman Peraturan Amnesti Pajak dan Persepsi yang baik atas Efektifitas Sistem Amnesti Pajak berpengaruh positif terhadap kemauan Wajib Pajak menjadi peserta Amnesti Pajak, sedangkan tingkat kepercayaan terhadap sistem pemerintahan dan hukum berpengaruh negatif pada kemauan wajib pajak menjadi peserta Amnesti Pajak. Dengan kata dapat dinyatakan bahwa semakin tinggi pengetahuan dan pemahaman peraturan perpajakan maka semakin banyak wajib pajak yang menjadi peserta amnesti pajak sehingga tingkat Kepatuhan Wajib Pajak pun menjadi tinggi.
Berdasarkan penelitian tersebut dapat dinyatakan hipotesis penelitian sebagai berikut. $\mathrm{H}_{3}$ : Pengetahuan Perpajakan berpengaruh terhadap hubungan antara pemahaman wajib pajak tentang Tax Amnesty dengan Kepatuhan Wajib Pajak

\section{Metodologi Penelitian}

\section{Objek Penelitian}

Populasi penelitian ini sangat luas karena meliputi wajib pajak orang usahawan yang berada di wilayah Jakarta Utara. Oleh karenanya, peneliti membatasi lingkup penelitian yang selanjutnya digunakan sebagai sampel penelitian adalah wajib pajak orang pribadi usahawan yang melakukan kegiatan usaha di kawasan pertokoan ITC Cempaka Mas, di wilayah Cempaka Putih, Jakarta.

\section{Variabel Penelitian}

Variabel Dependen. Variabel terikat dalam penelitian ini adalah kepatuhan wajib pajak orang pribadi (WPOP). Kepatuhan wajib pajak dapat didefinisikan sebagai perilaku Wajib Pajak yang taat dan melaksanakan kewajiban perpajakannya sesuai dengan ketentuan peraturan perundang-undangan perpajakan tanpa paksaan.

Variabel Independen. Variabel bebas dalam penelitian ini adalah tax amnesty. tax amensty menurut UU No. 11 Tahun 2016 adalah penghapusan pajak yang seharusnya terutang, tidak dikenai sanksi administrasi perpajakan dan sanksi pidana dibidang perpajakan dengan cara mengungkapkan harta dan membayar uang tebusan.

Variabel Moderasi. Variabel moderasi dalam penelitian ini adalah pengetahuan perpajakan. Berdasarkan penelitian Ni Ketut Dina Ambara Yani dan Naniek Noviari 
menyampaikan bahwa semakin tinggi pengetahuan dan pemahaman perpajakan maka semakin banyak wajib pajak yang menjadi peserta amnesti pajak sehingga dapat meningkatkan kepatuhan wajib pajak.

\section{Teknik Pengumpulan Data}

Pengumpulan data dilakukan dengan metode pengumpulan data studi komunikasi melalui instrumen kuesioner. Rancangan suatu kuesioner penelitian memerlukan ide yang kuat tentang jenis analisis yang akan dilakukan dan jenis skala yang diperlukan (Cooper dan Schindler, 2017:3). Kuesioner dalam penelitian ini terdiri dari dua bagian yaitu: data tentang diri responden dan pernyataan yang akan diajukan.

\section{Uji Validitas}

Uji Validitas biasanya digunakan untuk mengukur ketepatan suatu kuesioner apakah sudah tepat dalam mengukur apa yang ingin diukur. Uji validitas untuk menentukan apakah suatu item pertanyaan layak digunakan atau tidak, dilakukan dengan uji signifikansi koefisien korelasi pada tarif signifikansi 0,05, artinya suatu item dianggap valid jika berkorelasi signifikan terhadap skor total item. Metode pengujian validitas item dilakukan dengan aplikasi program SPSS yang bisa digunakan yaitu dengan metode korelasi Pearson atau metode Corrected Item-Total Correlation.

\section{Uji Reliabilitas}

Uji reliabilitas adalah alat untuk mengukur suatu kuesioner yang merupakan indikator dari variabel atau konstruk. Kuesioner dapat dikatakan reliabel jika jawaban seseorang terhadap pertanyaan tersebut konsisten atau stabil. Metode uji relibialitas yang sering digunakan adalah Cronbach's Alpha. Jika nilai Cronbach Alpha atau $\alpha>0.50$ maka instrument reliabel, tetapi jika Cronbach Alpha atau $\alpha<$ 0.50 maka instrument tidak reliabel

\section{Teknik Pengambilan Sampel}

Sampel yang dipilih oleh penulis dalam penelitian ini adalah wajib pajak orang pribadi usawahan di ITC Cempaka Mas. Teknik pengambilan sampel yang digunakan dalam penelitian ini adalah non-probability sampling dengan metode Judgement Sampling. Judgement Sampling adalah pengambilan sampel dengan memilih anggota sampel agar sesuai dengan beberapa kriteria (Cooper dan Schindler, 2017:79). Kriteria-kriteria yang ditentukan peneliti dalam penelitian ini untuk menentukan responden yang diperbolehkan mengisi kuesioner adalah wajib pajak orang pribadi yang melakukan kegiatan usaha di ITC Cempaka mas dan telah mengikuti tax amnesty.

Untuk menentukan jumlah sampel, peneliti menggunakan teknik penentuan jumlah sampel menurut Roscoe dalam Sugiyono (2012 :129), menentukan ukuran sampel yang tepat untuk kebanyakan penelitian yaitu ukuran sampel lebih dari 30 dan kurang dari 500 dikarenakan adanya keterbatasan waktu, tenaga, dan biaya, maka penulis hanya mengambil sampel sebanyak 100 orang responden.

\section{Teknik Analisis Data}

\section{Analisis Deskriptif}

Analisis deskriptif merupakan gambaran atau deskripsi suatu data yang dilihat dari nilai rata-rata (mean), standar deviasi, varian, maksimum, minimum, sum dan range (Ghozali.

\section{Uji Asumsi Klasik}

a) Uji Normalitas. Uji normalitas adalah pengujian yang bertujuan untuk menguji apakah dalam model regresi, variabel penggangu atau residual memiliki 
distribusi normal atau tidak. Model regresi yang baik adalah model regresi yang memiliki distribusi data normal atau mendekati normal. Uji normalitas dapat diuji dengan menggunakan uji Kolmogorov-Smirnov dengan pedoman pengambilan keptusan sebagai berikut: Jika nilai sig $<0,05$, maka distribusi data tidak normal. Jika nilai sig >0,05, maka a) distribusi data normal.

b) Uji Multikolonieritas. Uji multikolonieritas adalah pengujian yang bertujuan untuk menguji apakah model regresi ditemukan adanya korelasi antar variabel bebas (Independen). Model regresi yang baik seharusnya tidak terjadi korelasi antar variabel Independen. Pengujian multikolinearitas dilihat dari besaran VIF / Variance Inflation Factor dan nilai toleransi / tolerance. Kedua ukuran ini menunjukkan setiap variabel independen manakah yang dijelaskan oleh variabel independen lainnya. Tolerance mengukur variabilitas variabel Independen yang terpilih yang tidak dijelaskan oleh variabel Independen lainnya. Jadi nilai tolerance yang rendah sama dengan nilai VIF tinggi (karena VIF $=1 /$ Tolerance). Model regresi yang bebas dari multikolinieritas adalah mempunyai nilai Tolerance $\geq 0.10$ atau sama dengan nilai $\mathrm{VIF} \leq 10$.

c) Uji Heteroskedastisitas. Uji heteroskedastisitas adalah pengujian yang bertujuan untuk menguji apakah dalam model regresi terjadi ketidaksamaan variance dari residual satu pengamatan ke pengamatan yang lain. Jika varians dari residual satu pengamatan ke pengamatan lain tetap, maka disebut homoskedastisitas dan jika berbeda disebut heterokedastisitas. Model regresi yang baik adalah yang homokedastisitas atau tidak terjadi heterokedastisitas. Pengujian dengan Uji Glejser pada model regresi yang tidak terdapat heterokedastisitas adalah ketika memiliki variabel yang signifikan yaitu nilai sig $>0,05$. Namun, jika nilai sig $<0,05$, maka terdapat heterokesdastisitas.

d) Uji Autokorelasi. Uji autokorelasi adalah pengujian yang bertujuan untuk menguji apakah dalam model regresi ada korelasi antara kesalahan pengganggu pada periode $\mathrm{t}$ dengan kesalahan pengganggu pada periode t-1 (sebelumnya). Model regresi yang baik adalah regresi yang bebas dari autokorelasi. Untuk mendeteksi keberadaan autokorelasi, uji yang sering digunakan ialah uji Durbin-Watson (uji DW). Nilai Durbin-Watson (d) berkisar antara 0 sampai 4.

\section{Pengujian Hipotesis}

a) Uji Statistik F. Uji statistif f digunakan untuk mengetahui secara bersama-sama apakah variabel Independen berpengaruh secara signifikan atau tidak terhadap variabel Dependen. Tidak seperti uji t yang menguji signifikansi koefisien parsial regresi secara individu dengan uji hipotesis terpisah bahwa setiap koefisien regresi sama dengan nol. Kriteria pengujian yang dapat digunakan sebagai berikut: Ho diterima dan Ha ditolak apabila F hitung < $\mathrm{F}$ tabel dan tingkat sig $\mathrm{F}>0,05$. Ho ditolak dan Ha diterima apabila $\mathrm{F}$ hitung $>\mathrm{F}$ tabel dan tingkat sig $\mathrm{F}<0,05$.

b) Uji Statistik t. Uji statistik t pada dasarnya menunjukkan seberapa jauh pengaruh masing-masing variable Independen dalam menerangkan variabel Dependen. Kriteria pengujian yang dapat digunakan sebagai berikut:

i. Ho diterima dan Ha ditolak apabila $\mathrm{t}$ hitung $\langle\mathrm{t}$ tabel dan tingkat sig $\mathrm{t}\rangle$ 0,05 . Hal ini berarti variabel Independen secara individu tidak berpengaruh terhadap variabel Dependen.

ii. Ho ditolak dan Ha diterima apabila $\mathrm{t}$ hitung $>\mathrm{t}$ tabel dan tingkat $\operatorname{sig} \mathrm{t}<$ 0,05 . diterima. Hal ini berarti variabel Independen secara 
individu berpengaruh terhadap variabel Dependen.

c) Koefisien Determinasi $\left(\mathbf{R}^{2}\right)$. Koefisien determinasi $\left(\mathrm{R}^{2}\right)$ pada intinya mengukur seberapa jauh kemampuan model dalam menerangkan variasi variabel Dependen. Nilai koefisien determinasi adalah antara nol dan satu. Nilai $\mathbf{R}^{2}$ yang kecil berarti kemampuan variabel - variabel bebas (Tax
Amnesty dan Pengetahuan Perpajakan) dalam menjelaskan variasi variabel terikat (Kepatuhan Wajib Pajak Orang Pribadi) amat terbatas. Nilai yang mendekati 1 (satu) berarti variabel Dependen memberikan hampir semua informasi yang dibutuhkan untuk memprediksi variasi variabel Independen.

\section{Hasil Penelitian dan Pembahasan}

\section{Analisis Deskriptif}

Analisis Deskriptif Tax Amnesty

Tabel 1

Hasil Analsis Deskriptif

\begin{tabular}{|l|l|l|l|l|l|l|}
\hline & N & Minimum & Maximum & Mean & Std. Deviation & Variance \\
\hline P1 & 100 & 1 & 5 & 4.14 & 1.341 & 1.798 \\
P2 & 100 & 2 & 5 & 4.16 & .896 & .802 \\
P3 & 100 & 2 & 5 & 4.23 & .908 & .825 \\
P4 & 100 & 2 & 5 & 4.22 & .883 & .779 \\
P5 & 100 & 1 & 5 & 3.93 & 1.208 & 1.460 \\
P6 & 100 & 1 & 5 & 3.96 & 1.171 & 1.372 \\
P7 & 100 & 1 & 5 & 4.27 & 1.171 & 1.371 \\
Valid N (listwise) & 100 & & & & & \\
\hline
\end{tabular}

Sumber : hasil olah data

Berdasarkan hasil tabel diatas, dapat disimpulkan bahwa nilai rata-rata responden menjawab pernyataan tentang tax amnesty pada pernyataan nomor $1,2,3,4$, dan 7 menjawab Setuju dengan nilai 4 (empat), dan untuk pernyataan nomor 5 dan 6 menjawab ragu-ragu dengan nilai 3 (tiga).

\section{Analisis Deskriptif Pengetahuan Perpajakan}

Tabel 2

Hasil Analisis Deskriptif

\begin{tabular}{|c|c|c|c|c|c|c|}
\hline & N & Minimum & Maximum & Mean & Std. Deviation & Variance \\
\hline P1 & 100 & 1 & 5 & 4.22 & 1.244 & 1.547 \\
P2 & 100 & 1 & 5 & 4.34 & 1.075 & 1.156 \\
P4 & 100 & 1 & 5 & 4.13 & 1.012 & 1.023 \\
P5 & 100 & 1 & 5 & 4.19 & .982 & .964 \\
P6 & 100 & 1 & 5 & 4.27 & .952 & .906 \\
P7 & 100 & 1 & 5 & 3.97 & 1.077 & 1.161 \\
Valid N (listwise) & 100 & 1 & 5 & 4.46 & .937 & .877 \\
\hline
\end{tabular}


Berdasarkan hasil tabel, dapat disimpulkan bahwa nilai rata-rata responden menjawab pernyataan tentang tax amnesty pada pernyataan nomor $1,2,3,4,5$, dan 7 menjawab setuju dengan nilai 4 (empat), dan untuk pernyataan nomor 6 menjawab ragu-ragu dengan nilai 3 (tiga).

\section{Analisis Deskriptif Pengetahuan Perpajakan}

Tabel 3

Hasil Analsis Deskriptif

\begin{tabular}{|l|l|l|l|l|l|l|}
\hline & $\mathrm{N}$ & Minimum & Maximum & Mean & Std. Deviation & Variance \\
\hline P1 & 100 & 1 & 5 & 4.19 & 1.169 & 1.368 \\
P2 & 100 & 1 & 5 & 4.56 & .756 & .572 \\
P3 & 100 & 2 & 5 & 4.24 & .793 & .629 \\
P4 & 100 & 1 & 5 & 4.12 & .935 & .874 \\
P5 & 100 & 1 & 5 & 4.03 & 1.132 & 1.282 \\
P6 & 100 & 2 & 5 & 4.36 & .759 & .576 \\
P7 & 100 & 1 & 5 & 4.17 & .995 & .991 \\
P8 & 100 & 2 & 5 & 4.45 & .730 & .533 \\
P9 & 100 & 1 & 5 & 4.30 & 1.159 & 1.343 \\
Valid N (listwise) & 100 & & & & & \\
\hline
\end{tabular}

Sumber : hasil olah data

Berdasarkan hasil tabel, dapat disimpulkan bahwa nilai rata-rata responden menjawab pernyataan tentang kepatuhan wajib

\section{Uji Validitas}

Uji validitas dilakukan untuk mengetahui apakah suatu data valid atau tidak kuesionernya. Pengujian ini dilakukan dengan Pearson Correlation. Kriteria valid untuk setiap butir pernyataan di dalam masing-masing variabel adalah asumsi $r$ hitung lebih besar dari $r$ tabel $(0,361)$ dan bernilai positif. Berikut adalah tabel validitas dari setiap pernyataan yang ada di dalam kuesioner.

\section{Uji Reliabilitas}

Uji realibilitas dilakukan untuk mengetahui apakah suatu data reliabel atau tidak kuesionernya. Penelitian ini menggunakan Cronbach Alpha untuk menguji reliabilitas. Setelah mendapatkan Cronbach pajak pada semua pernyataan nomor menjawab setuju dengan nilai 4 (empat).

Tabel 4

\section{Hasil Uji Validitas}

\begin{tabular}{|c|c|}
\hline Insturmen Variabel & $\begin{array}{c}\text { Nilai r hitung } \\
\text { terkecil }\end{array}$ \\
\hline Tax Amnesty & 0,694 \\
\hline $\begin{array}{c}\text { Pengetahuan } \\
\text { Perpajakan }\end{array}$ & 0,559 \\
\hline $\begin{array}{c}\text { Kepatuhan Wajib } \\
\text { Pajak }\end{array}$ & 0,586 \\
\hline
\end{tabular}

Sumber : hasil olah data

Alpha, maka penulis akan membandingkan dengan nilai standar output yaitu sebesar 0,50. Berikut ini adalah tabel uji untuk reliabilitas untuk setiap variabel yang ada. 
Tabel 5

Hasil Uji Reliabilitas

\begin{tabular}{|c|c|}
\hline $\begin{array}{c}\text { Instrumen } \\
\text { Variabel }\end{array}$ & $\begin{array}{c}\text { Nilai } \\
\text { Cronbach's } \\
\text { Alpha }\end{array}$ \\
\hline Tax Amnesty & 0,844 \\
\hline $\begin{array}{c}\text { Pengetahuan } \\
\text { Perpajakan }\end{array}$ & 0,893 \\
\hline $\begin{array}{c}\text { Kepatuhan Wajib } \\
\text { Pajak }\end{array}$ & 0,905 \\
\hline
\end{tabular}

Sumber : hasil olah data

\section{Uji Asumsi Klasik}

\section{Uji Normalitas}

Uji normalitas dilakukan untuk mengetahui apakah data yang akan digunakan dalam model regresi berdistribusi normal atau tidak. Metode yang digunakan untuk menguji normalitas adalah dengan menggunakan uji Kolmogrov Smirnov dengan tingkat signifikansi $5 \%$ atau 0,05 .

Hasil uji normalitas yang dilakukan disajikan pada tabel 6 berikut.

Tabel 6

\section{Hasil Uji Normalitas}

\begin{tabular}{|c|c|}
\hline $\begin{array}{c}\text { Nilai Asymp. Sig } \\
\text { (2-tailed) }\end{array}$ & 0,103 \\
\hline
\end{tabular}

Sumber : hasil olah data

Berdasarkan perhitungan uji normalitas dengan bantuan software IBM SPSS Statistics 22 menggunakan Kolmogrov Smirnov pada tabel 4.10 didapatkan tingkat signifikansi 0,103 . Dengan tingkat sig lebih besar dari 0,05, maka dapat ditarik kesimpulan bahwa ketiga variabel tersebut berdistribusi normal.

\section{Uji Multikolinearitas}

Uji multikolinearitas dilakukan untuk menguji apakah di dalam model regresi ditemukan adanya korelasi antar variabel bebas (variabel independen). Multikolinearitas dapat dilakukan dengan nilai TOL (Tolerance) dan VIF (Varian Inflation Factor) dari masingmasing variabel bebas terhadap variabel terikatnya (variabel dependen).

Hasil uji multikolinearitas yang dilakukan untuk menguji kerangka pemikiran dimana terdapat 2 variabel bebas dan 1 variabel terikat disajikan dalam tabel 7 berikut.

Tabel 7

Hasil Uji Multikolinearitas

\begin{tabular}{|c|c|c|}
\hline \multirow{2}{*}{ Model } & \multicolumn{2}{|c|}{ Colinearity Statistics } \\
\cline { 2 - 3 } & Tolerance & VIF \\
\hline Tax Amnesty & 0,888 & 1,127 \\
\hline $\begin{array}{c}\text { Pengetahuan } \\
\text { Perpajakan }\end{array}$ & 0,888 & 1,127 \\
\hline \\
Sumber : hasil olah data
\end{tabular}

Dari tabel 7 tersebut tampak bahwa nilai Tolerance lebih dari 0,10 dan nilai VIF kurang dari 10, maka dapat ditarik kesimpulan bahwa kedua variabel bebas yang terdapat dalam model tidak terdapat gejala multikolinieritas.

\section{Uji Heterokedastisitas}

Uji heterokedastisitas bertujuan untuk menguji apakah dalam model regresi terjadi ketidaksamaan varian dari residual satu pengamatan ke pengamatan yang lain. Model regresi yang baik adalah homokedastisitas atau tidak terjadi heterokedastisitas. Cara yang digunakan untuk mendeteksi heterokedastisitas adalah dengan menggunakan hasil Uji Glejser. Hasil uji heterokedastisitas disajikan dalam tabel 8 berikut.

Tabel 8

Hasil Uji Heterokedastisitas

\begin{tabular}{|c|c|}
\hline Model & Sig \\
\hline Tax Amnesty & 0,062 \\
\hline $\begin{array}{c}\text { Pengetahuan } \\
\text { Perpajakan }\end{array}$ & 0,166 \\
Sumber : hasil olah data
\end{tabular}


Dari tabel 8 tersebut tampak bahwa nilai sig lebih dari 0,05, maka dapat ditarik kesimpulan bahwa kedua variabel bebas yang terdapat dalam model tidak terdapat gejala heterokedastisitas.

\section{Uji Autokorelasi}

Uji autokorelasi digunakan untuk mengetahui ada atau tidaknya penyimpangan asumsi klasik autokorelasi yaitu korelasi yang terjadi antara residual pada satu pengamatan dengan pengamatan yang lain pada model regresi. Prasyarat yang harus dipenuhi adalah tidak adanya autokorelasi pada model regresi. Cara yang digunakan untuk mendeteksi autokorelasi adalah dengan mengunakan uji Durbin Watson. Hasil uji autokorelasi disajikan dalam tabel 9 berikut.

Tabel 9

Hasil Uji Autokorelasi

\begin{tabular}{|c|c|}
\hline Model & Durbin Watson \\
\hline Tax Amnesty dan & 2,215 \\
Pengetahuan & \\
Perpajakan & \\
\hline
\end{tabular}

Sumber : hasil olah data

Didapatkan hasil uji durbin Watson menunjukkan angka 2,038, du sebesar 1,7364, dan 4-du sebesar 2,2636. Dengan demikian kesimpulan yang didapatkan adalah tidak ada autokorelasi, karena du < d < 4-du $(1,7152<$ $2,215<2,2848)$.

\section{Uji Hipotesis}

\section{Koefisien Determinasi}

Tabel 10

Koefisien Determinasi

\begin{tabular}{|c|c|c|c|}
\hline R & R Square & $\begin{array}{c}\text { Adjusted } \\
\boldsymbol{R} \\
\text { Square }\end{array}$ & $\begin{array}{c}\text { Std. Error } \\
\text { of the } \\
\text { Estimate }\end{array}$ \\
\hline 0,5090 & 0,259 & 0,236 & 5,105 \\
\hline
\end{tabular}

Sumber : hasil olah data
Dari hasil pengujian di tabel 10 diatas, nilai Adjusted $R$ Square sebesar 0,236 menunjukan hanya sebesar $23,6 \%$ variabel kepatuhan wajib pajak yang bisa dijelaskan oleh variabel interaksi antara tax amnesty dan pengetahuan perpajakan,sedangkan sisanya $76,4 \%$ dijelaskan oleh faktor-faktor lain yang tidak dijelaskan dalam model regresi.

\section{Uji F}

Tabel 11

Hasil Nilai Uji F

\begin{tabular}{|c|c|c|}
\hline Model & F & Sig. \\
\hline Regression & 11,205 & 0,000 \\
\hline
\end{tabular}

Sumber : hasil olah data

Dari hasil pengujian di tabel 11 di atas, nilai $F_{\text {hitung }}$ adalah sebesar 11,205 dengan tingkat signifikansi 0,000 lebih kecil dari 0,05. Hal ini menunjukan bahwa model persamaan regresi berganda fit dan layak digunakan untuk melakukan pengujian.

\section{Uji t}

Tabel 11

Hasil Uji t

\begin{tabular}{|l|c|c|c|}
\hline \multicolumn{1}{|c|}{ Model } & B & t & Sig. \\
\hline Constant & 1,21 & 0,11 & 0,91 \\
X1 (Tax & 2 & 1 & 2 \\
Amnesty & 0,92 & 2,27 & 0,02 \\
X2 & 5 & 7 & 5 \\
(Pengetahua & 1,11 & 2,86 & 0,00 \\
n & 3 & 1 & 5 \\
Perpajakan) & - & - & 0,06 \\
X1X2(Intera & 0,02 & 1,84 & 8 \\
ksi X1 \& & 6 & 4 & \\
X2) & & & \\
\hline
\end{tabular}

Sumber : hasil olah data

Persamaan regresi yang diperoleh

$Y=1,212+0,925 X_{1}+1,113 X_{2}-0,026 X_{1} X_{2}$

Dari hasil pengujian di tabel 12 diatas, menunjukan thitung variabel tax amnesty adalah 
sebesar 2,277 dengan signifikansi t bernilai 0,025 (signifikan). Variabel pengetahuan perpajakan mempunyai $t_{\text {hitung }}$ sebesar 2,861 dengan signifikansi 0,005 (signifikan). Variabel interaksi antara tax amnesty dan pengetahuan perpajakan mempunyai $t_{\text {hitung }}$ sebesar -1,844 dengan signifikansi 0,068. Hal ini menunjukan variabel pengetahuan perpajakan tidak berpengaruh dalam memoderasi hubungan tax amnesty dan kepatuhan wajib pajak.

\section{Pembahasan}

\section{Pengaruh Tax Amnesty terhadap Kepatuhan Wajib Pajak}

Pengaruh variabel tax amnesty dapat dilihat dari hasil uji nilai $t_{\text {hitung }}$ dalam analisis regresi berganda yaitu sebesar 2,277 dengan signifikansi t sebesar 0,025 (signifikan). Hal ini sejalan dengan hipotesis pertama dan penelitian Nurulita Rahayu (2017) dan Viega Ayu Permata Sari (2017) yang mengatakan bahwa tax amnesty berpengaruh positif dan signifikan terhadap kepatuhan wajib pajak.

\section{Pengaruh Pengetahuan Perpajakan terhadap Kepatuhan Wajib Pajak}

Pengaruh variabel tax amnesty dapat dilihat dari hasil uji nilai $t_{\text {hitung }}$ dalam analisis regresi berganda yaitu sebesar 2,277 dengan signifikansi t sebesar 0,025 (signifikan). Hal ini sejalan dengan hipotesis pertama dan penelitian Nurulita Rahayu (2017) dan Viega Ayu Permata Sari (2017) yang mengatakan bahwa tax amnesty berpengaruh positif dan signifikan terhadap kepatuhan wajib pajak.

\section{Pengaruh Pengetahuan Perpajakan dalam memoderasi hubungan antara Tax Amnesty terhadap Kepatuhan Wajib Pajak}

Pengaruh variabel interaksi antara tax amnesty dan pengetahuan perpajakan dapat dilihat dari hasil uji nilai $t_{\text {hitung }}$ dalam analisis regresi berganda yaitu sebesar $-1,844$ dengan signifikansi t sebesar 0,068 (tidak signifikan). Hal ini tidak sejalan dengan hipotesis ketiga dan penelitian Ni Ketut Dina dan Naniek Noviari (2017) yang mengatakan bahwa pengetahuan perpajakan berpengaruh positif dan signifikan terhadap kemauan wajib pajak menjadi peserta tax amnesty. Hal ini menunjukan bahwa variabel pengetahuan perpajakan dapat dikatakan variabel moderasi jenis predictor moderating / moderasi prediktor (Ghozali, 2016:214) yang artinya variabel pengetahuan perpajakan hanya berperan sebagai variabel independen dan tidak dapat berperan sebagai variabel moderasi.

\section{Simpulan dan Saran}

Berdasarkan hasil analisis dan pembahasan, maka dapat disimpulkan sebagai berikut: Bahwa terbukti tax amnesty berpengaruh positif dan signifikan terhadap kepatuhan wajib pajak orang pribadi usahawan. Bahwa terbukti pengetahuan perpajakan berpengaruh positif dan signifikan terhadap kepatuhan wajib pajak orang pribadi usahawan. Bahwa tidak cukup bukti bahwa pengetahuan perpajakan berpengaruh dalam memoderasi hubungan antara tax amnesty terhadap kepatuhan wajib pajak orang pribadi usahawan.

Dalam rangka pengembangan ke depan, maka peneliti memberikan saran untuk penelitian lanjutan, yaitu perlu meningkatkan jumlah sampel yang menunjukkan keterwakilan wilayah penelitian yang lebih luas, sehingga hasilnya akan lebih mendekati dengan kenyataan dan dapat lebih bermakna dalam pengambilan keputusan.

\section{Daftar Pustaka}

Agus, S. (2016, 10 31). Ahli Pajak Dukung Kebijakan Tax Amnesty. Retrieved from

http://www.hukumonline.com/berita/ baca/lt58172bc9bf9cd/ahli-pajak- 
dukung-kebijakan-tax-amnesty-begini-alasannya

Bona, M. F. (2017, 8 12). Pemerintah Sosialisasi Pentingnya Pajak Ke Sekolah-sekolah. Retrieved from http://www.beritasatu.com/bisnis/44 6855-pemerintah-sosialisasipentingnya-pajak-kesekolahsekolah.html

Caroko, B., Susilo, H., \& A, Z. Z. (2015). Pengaruh Pengetahuan Perpajakan, Kualitas Pelayanan Pajak Dan Sanksi Pajak Terhadap Motivasi Wajib Pajak Orang Pribadi Dalam Membayar Pajak. Jurnal Perpajakan (JEJAK), 1(1), 1-10.

Cooper, D. R., \& Schindler, P. S. (2017). Metode Penelitian Bisnis. Jakarta: Salemba Empat.D. J. (2016). Amnesti Pajak. Retrieved from Pajak.go.id: http://www.pajak.go.id/content/amne sti-pajak

Direktorat Jenderal Pajak. (n.d.). Peraturan Menteri Keuangan Republik Indonesia Nomor 74/PMK.03/2012. Retrieved from http://ketentuan.pajak.go.id/aturan/as li/74.PMK03.2012.pdf

Direktorat Jenderal Pajak. (n.d.). UndangUndang Republik Indonesia Nomor 11 Tahun 2016. Retrieved from Pajak.go.id:

http://ketentuan.pajak.go.id/index.ph $\mathrm{p} ? \mathrm{r}=$ aturan/rinci\&idcrypt $=\mathrm{oJqgpKE}$ $\% 3 \mathrm{D}$

Direktorat Jenderal Pajak. (n.d.). UndangUndang Republik Indonesia Nomor 28 Tahun 2007. Retrieved from Pajak.go.id:

http://ketentuan.pajak.go.id/index.ph $\mathrm{p} ? \mathrm{r}=$ aturan/rinci\&idcrypt $=\mathrm{oJamop} 0$ $\% 3 \mathrm{D}$

Etivitawati, Nurlaela, S., \& Titisari, K. H. (2017). Pengaruh Pemahaman, Pengetahuan Dan Tax Amnesty Terhadap Kepatuhan Membayar
Pajak Orang Pribadi. Seminar Nasional IENACO, 743-749.

Ghozali, I. (2016). Aplikasi Analisis Multivariete. Semarang: Universitas Diponegoro.

Husnurrosyidah . (2016). Pengaruh Tax Amnesty Dan Sanksi Pajak Terhadap Kepatuhan Wajib Pajak di BMT- SeKaresidenan Pati. Jurnal Ekonomi Syariah, 4(2), 211-226.

Hutasoit, G. (2017). Pengaruh Tax Amnesty Terhadap Kepatuhan Wajib Pajak Di Kota Palembang. Seminar Nasional Teknologi Informasi, Bisnis, dan Desain, 43-48.

Mardiasmo. (2016). Perpajakan Edisi Terbaru 2016. Yogyakarta: ANDI.

Ngadiman, \& Huslin, D. (2015). Pengaruh Sunset Policy, Tax Amnesty, Dan Sanksi Pajak Terhadap Kepatuhan Wajib Pajak (Studi Empiris di Kantor Pelayanan Pratama Jakarta Kembangan). Jurnal Akuntansi, 19(2), 225-241.

Notoatmodjo, S. (2013). Promosi Kesehatan Teori dan Aplikasi. Jakarta: Rineka Cipta.

Nugroho, A. A. (2016, 7 25). Tax Amnesty Sebagai Sarana Sosialisasi Pajak. Retrieved from http://www.pajak.go.id/content/articl e/tax-amnesty-sebagai-saranasosialisasi-pajak

Panama Papers. (n.d.). Retrieved from Wikipedia:

https://id.wikipedia.org/wiki/Panama _Papers

Rahayu, N. (2017). Pengaruh Pengetahuan Perpajakan, Ketegasan Sanksi Pajak, Dan Tax Amnesty Terhadap Kepatuhan Wajib Pajak. Akuntansi Dewantara, 1(1), 15-30.

Rahayu, S. K. (2013). Perpajakan Indonesia; Konsep \& Aspek Formal. Jakarta: Graha Ilmu. 
Rahmah, G. (2017, 4 2). Beberapa Penyebab Target Tax Amnesty Tak Tercapai. Retrieved from https://bisnis.tempo.co/read/861850/ beberapa-penyebab-target-taxamnesty-tak-tercapai

Safyra, P. (2017, 4 3). CORE: Hasil Tax Amnesty Jauh dari Ekspetasi. Retrieved from https://www.cnnindonesia.com/ekon omi/20170403103842-78-

204494/core-hasil-tax-amnesty-jauhdari-ekspektasi

Sari, V. A. (2017). Pengaruh Tax Amnesty, Pengetahuan Perpajakan, Dan Pelayanan Fiskus Terhadap Kepatuhan Wajib Pajak. Jurnal Ilmu dan Riset Akuntansi, 6(2), 744-760.
Sihaloho, M. J. (2016, 4 6). "Panama Papers" Buktikan Pajak Tinggi Akan Cenderung Dihindari. Retrieved from http://www.beritasatu.com/ekonomi/ 358620-panama-papers-buktikanpajak-tinggi-akan-cenderungdihindari.html

Sugiyono. (2012). Metode Penelitian Bisnis. Bandung: Alfabeta.

Waluyo. (2017). Perpajakan Indonesia. Jakarta: Salemba Empat.

Yani, N. D., \& Noviari, N. (2017). Faktor Faktor Yang Mempengaruhi Kemauan Wajib Pajak Menjadi Peserta Amnesti Pajak. E-Jurnal Akuntansi Universitas Udayana, 20(1), 585-614. 